\title{
The effect of different physical forms of starter feed on rumen fermentation indicators and weight gain in calves after weaning
}

\author{
Leoš Pavlata, Ondřej Št’astník, Štěpánka Křivová, Hana Dočkalová, Lenka Sedláková, \\ Eva Mrkvicová, Petr Doležal
}

Mendel University in Brno, Faculty of AgriSciences, Department of Animal Nutrition and Forage Production, Brno, Czech Republic

Received January 5, 2017

Accepted May 31, 2017

\begin{abstract}
The aim of the study was to determine the effect of different physical forms of starter feed on rumen fermentation indicators of calves after weaning and their weight gain. The experiment was performed with Czech Fleckvieh calves after weaning. The calves were fed ad libitum completely pelleted starter feed or texturized starter feed with chopped straw. The rumen fluid samples were collected after a month of feeding the starter feeds. The calves were weighed monthly. The $\mathrm{pH}$, total acidity, total volatile fatty acids, acetate, propionate, butyrate, lactic acid, ammonia and the number of rumen ciliate protozoa were determined in the rumen fluid samples. The calves receiving the starter feed with straw showed significantly higher rumen $\mathrm{pH}(6.24 \pm 0.51 \mathrm{vs}$. 5.58 $\pm 0.30)$, total volatile fatty acids $(98.02 \pm 20.46 \mathrm{vs} .61 .40 \pm 26.51 \mathrm{mmol} / \mathrm{l})$, molar proportion of acetate $(61.20 \pm 4.87$ vs. $50.53 \pm 4.66 \%)$, and the acetate:propionate ratio $(2.38 \pm 0.53$ vs. 1.34 $\pm 0.18)$ and lower molar proportion of propionate $(26.55 \pm 4.48$ vs. $37.92 \pm 3.58 \%)$ compared with the calves receiving pelleted starter feed. Average daily gain of the calves did not differ significantly. The feeding of starter feed with chopped straw compared with the pelleted starter feed led to better development of the rumen fermentation evaluated by rumen $\mathrm{pH}$, by total volatile fatty acids production, and by the proportion and ratio of acetic and propionic acids. The feeding of starter feed with chopped straw reduced the occurrence of subacute ruminal acidosis in the weaned calves.
\end{abstract}

Volatile fatty acids, pelleted starter, starter with chopped straw, subacute ruminal acidosis

Calves are born with a physically and metabolically undeveloped rumen. In nature, calves obtain nutrients from milk and forages. On dairy farms, calves are mostly fed restricted amounts of milk and weaned onto starter feeds (Khan et al. 2016). Early transition to functional rumen microbial fermentation is economically important in dairy calves (Khan et al. 2007).

Research during recent years has shown the effect of providing more milk on improving calf growth and future productivity, which requires a re-evaluation of the effects of starter feed composition and forage on the rumen fermentation and performance of calves (Khan et al. 2011; Terré et al. 2015). Modern starters are composed mainly of mashed cereal, corn, oats, barley, soybeans and components comprising structured fibre (SuarezMena et al. 2015). Grain texture plays a major role in the rate and site of starch digestion (Philippeau et al. 1999). Starter feeds are divided based on physical structure into finely ground/meal, pelleted, textured/multiparticle, mashed, with chopped forage, and some combinations. The results of experiments concerned with physical forms of starter feeds are inconsistent (Franklin et al. 2003; Bach at al. 2010; Pezhveh et al. 2014; Terré et al. 2015; Dockalova et al. 2016). Besides, most experiments are performed on Holstein calves during milk nutrition. Further research is therefore necessary.

The feeding of high starch and low fibre starter feeds may negatively affect rumen development. Forage supplementation is therefore beneficial for the development of the

Address for correspondence:

doc. MVDr. Leoš Pavlata, Ph.D.

Department of Animal Nutrition and Forage Production

Faculty of AgriSciences

Mendel University in Brno

Zemědělská 1, 61300 Brno, Czech Republic

Phone: +420 545133166

E-mail: leos.pavlata@mendelu.cz

http://actavet.vfu.cz/ 
gut and rumination of calves (Khan et al. 2016). Feeding diets with high amounts of readily fermentable carbohydrates may reduce ruminal $\mathrm{pH}$, and therefore, feeding a fibre source in dairy calves is necessary for rumen health (Thomas and Hinks 1982; Beharka et al. 1998). The chopped forage in starter diet for calves prevents hyperkeratinisation of papillae and affects rumen $\mathrm{pH}$ (Grenwood et al 1997; Terré et al. 2015). Chopped hay feeding increases dry matter intake and growth in dairy calves (Castells et al. 2012a) and forage supplemented calves have lower rumen volatile fatty acids (VFA) than nonsupplemented calves (Castells et al. 2012b). These findings lead to the consideration that forage supplementation might help VFA absorption (Castells et al. 2012b). Forage provision seems to be the preferred strategy to improve pelleted starter feed intake and performance of calves in comparison to an increase fibre content of concentrate (Terré et al. 2013).

The aim of the study was to determine the effect of different physical forms of starter feed on rumen fermentation indicators of calves after weaning and on the calves' weight gain.

\section{Materials and Methods}

The experiment was performed on a dairy cattle farm in late summer to early autumn of 2016. The experiment included Czech Fleckvieh female calves $(\mathrm{n}=12)$ after weaning (approximately $60^{\text {th }}$ day of age). The calf monitoring was divided into 3 periods (Table 1).

Table 1. Experimental design.

\begin{tabular}{lcl}
\hline Period & Age of calves & \multicolumn{1}{c}{ Nutrition } \\
\hline 1 Preparation period & $0-60$ & $\begin{array}{l}\text { Colostrum/milk + pelleted starter with 20\% } \\
\text { of whole oats (Table 2) } \\
\text { Group PEL - pelleted starter + meadow hay } \\
\text { Group CHS - textured starter with chopped } \\
\text { straw + meadow hay (Table 3) }\end{array}$ \\
3 Post-experimental period & $60-90$ & Total mixed ration (Table 4) \\
\hline
\end{tabular}

Calf rearing and feeding before the start of the experiment

After birth, the umbilical cord of the calves was treated, and the calves were weighed. Calves were fed 2 1 of colostrum within two hours after birth. Second colostrum feeding (2 1) was carried out after six hours.

Table 2. Nutrient composition of the starter feed (in milk feeding period of calves - day 0 to 60 of age).

\begin{tabular}{lc}
\hline & Pelleted starter $^{\mathrm{x}}$ with $20 \%$ of whole oats \\
\hline Dry matter (\%) & 95.24 \\
Ash (\%) & 7.50 \\
Crude protein (\%) & 18.89 \\
Ether extract (\%) & 4.58 \\
Fibre (\%) & 9.94 \\
ADF (\%) & 13.32 \\
NDF (\%) & 25.80 \\
\hline
\end{tabular}

'Starter feed contains: wheat bran, malt sprouts, distiller's residue, wheat, solvent-extracted rapeseed meal, solvent-extracted soybean meal, beet molasses, sugar beet pulp, rye bran, oat, calcium carbonate, premix of additives (per kg): vitamin A 30000 IU, vitamin D3 5000 IU, vitamin E (all-rac-alfa-tocopherol) 60 mg, copper sulfate pentahydrate $20 \mathrm{mg}$, zinc sulphate monohydrate $80 \mathrm{mg}$, manganese oxide $60 \mathrm{mg}$, ferrous sulphate monohydrate $100 \mathrm{mg}$, anhydrous calcium iodate $2 \mathrm{mg}$

$\mathrm{ADF}$ - acid detergent fibre; NDF - neutral detergent fibre 
Subsequently, the calves were placed into individual outdoor pens and fed colostrum $/ \mathrm{milk} \times 3$ a day at the total amount of 71 per animal per day $(2.5+2.0+2.51)$, pelleted starter with the addition of whole oats (Table 2$)$, and drinking water ad libitum.

In the experimental period, the calves were randomly divided into two groups (group PEL and group CHS) of six calves each, and weighed (Table 6). Calves were fed ad libitum the respective type of commercially produced starter feed (pelleted starter feed in group PEL; textured starter feed with chopped straw in group CHS), meadow hay, and drinking water (Table 3). The size of the pelleted starter feed used was $4 \mathrm{~mm}$ in diameter and $10-15 \mathrm{~mm}$ in length. Each calf group was housed in a separate group pen.

Table 3. Nutrient composition of the experimental diets (laboratory analysis).

\begin{tabular}{lccc}
\hline & $\begin{array}{c}\text { Pelleted starter } \\
\text { group PEL }\end{array}$ & $\begin{array}{c}\text { Textured starter with chopped straw } \\
\text { group CHS }\end{array}$ & $\begin{array}{c}\text { Meadow hay }^{\mathrm{y}} \\
\text { groups PEL and CHS }\end{array}$ \\
\hline Dry matter (\%) & 95.14 & 94.72 & 93.96 \\
Ash (\%) & 8.28 & 7.72 & 6.99 \\
Crude Protein (\%) & 21.17 & 17.33 & 12.19 \\
Ether extract (\%) & 4.80 & 2.26 & 2.70 \\
Fibre (\%) & 9.22 & 11.34 & 26.26 \\
ADF (\%) & 12.94 & 13.82 & 30.91 \\
NDF (\%) & 25.93 & 25.51 & 51.18 \\
\hline
\end{tabular}

x Pelleted starter feed contains: wheat bran, malt sprouts, distiller's residue, wheat, solvent-extracted rapeseed meal, solvent-extracted soybean meal, beet molasses, sugar beet pulp, rye bran, oat, calcium carbonate, premix of additives (per kg): vitamin A $30000 \mathrm{IU}$, vitamin D3 $5000 \mathrm{IU}$, vitamin E (all-rac-alpha-tocopherol) $60 \mathrm{mg}$, copper sulfate pentahydrate $20 \mathrm{mg}$, zinc sulphate monohydrate $80 \mathrm{mg}$, manganese oxide $60 \mathrm{mg}$, ferrous sulphate monohydrate $100 \mathrm{mg}$, anhydrous calcium iodate $2 \mathrm{mg}$

y Textured starter with chopped straw contains: crushed barley, extruded corn, solvent-extracted soybean meal, wheat bran, chopped wheat straw, crushed wheat, solvent-extracted rapeseed meal, limestone + premix additives (calcium carbonate, sodium chloride, dicalcium phosphate, magnesium oxide, wheat bran, sodium calcium phosphate, beet molasses), brewer's yeast Saccharomyces cerevisiae, beet molasses, feed salt

$\mathrm{ADF}$ - acid detergent fibre; NDF - neutral detergent fibre

Table 4. Nutrient composition of the total mixed ration (TMR) which calves fed after the end of starter feeding $\left(90^{\text {th }}\right.$ to $150^{\text {th }}$ day of age $)$

\begin{tabular}{lr}
\hline & TMR $^{\mathrm{x}}$ \\
\hline Dry matter (\%) & 95.29 \\
Ash (\%) & 8.06 \\
Crude Protein (\%) & 14.18 \\
Ether extract (\%) & 3.42 \\
Fibre (\%) & 19.16 \\
ADF (\%) & 23.32 \\
NDF (\%) & 33.55
\end{tabular}

x TMR contains: meadow hay, corn silage, grass silage, beet molasses, concentrate feed mixture (wheat $22 \%$, barley $30 \%$, triticale $10 \%$, solventextracted soybean meal 11\%, solvent-extracted rapeseed meal $23 \%$, milled limestone $1.5 \%$, feeding salt $1.0 \%$, monocalcium phosphate $0.25 \%$, vitamin and mineral premix $0.15 \%$ )

ADF - acid detergent fibre; NDF - neutral detergent fibre
The rumen liquid from each calf was collected after 30 days of feeding different types of starters (calves aged about 90 days), using a stomach tube and a vacuum pump. The rumen fluid was passed, preserved and forwarded to laboratory analysis. The rumen fluid samples were preserved by toluene for determining volatile fatty acids (VFA), by formaldehyde for determining ciliate protozoa, and by mercuric chloride for determining other indicators. The following properties of ruminal fluid were examined: $\mathrm{pH}$, total titratable acidity, ciliate protozoa count, lactic acid concentration, ammonia, total VFA, and the percentage of individual acids (acetic, propionic, and butyric). The $\mathrm{pH}$ level was measured by the $\mathrm{pH}$ Meter GPH 014 (Greisinger Electronic GmbH, Germany). Total acidity was established by the titration method. Volatile fatty acids were determined by gas chromatography (Trace GC Ultra, Thermo Fisher Scientific, USA). Lactic acid was measured with the use of the test kit cat. LC 2389 (Randox Laboratories, UK). Ammonia was determined by the test kit cat. AM 1054 (Randox Laboratories, UK).

The calves were weighed and in the following days gradually transferred to feeding on total mixed ration (TMR). The TMR (Table 4) was administered until the 
end of the monitored period at the age of 150 days. The calves were regularly weighed and average daily weight gains of calves were calculated.

Data between the groups were analysed using one-way ANOVA by STATISTICA software. Differences among experimental groups were assessed using Scheffe's test. Significance was declared at $P<0.05$.

\section{Results}

The results of the analysis of the calves' rumen fluid samples collected after 1 month of feeding different starter feeds are presented in Table 5.

Table 5. Rumen fluid properties of calves fed complete pelleted starter feed (group PEL) or textured starter feed with chopped straw (group CHS).

\begin{tabular}{lcccc}
\hline & \multicolumn{2}{c}{ Group PEL $(\mathrm{n}=6)$} & \multicolumn{2}{c}{ Group CHS $(\mathrm{n}=6)$} \\
\cline { 2 - 5 } & Mean \pm SD & Range & Mean \pm SD & Range \\
\hline Rumen pH & $5.58 \pm 0.30^{*}$ & $5.21-6.04$ & $6.24 \pm 0.51^{*}$ & $5.48-7.07$ \\
pH decrease below 6.2 & $0.62 \pm 0.30^{*}$ & $0.16-0.99$ & $0.13 \pm 0.29^{*}$ & $0-0.72$ \\
Total titratable acidity & & & & $10.5-30.1$ \\
(titratable units) & $18.67 \pm 5.61$ & $11.0-26.0$ & $16.80 \pm 7.14$ & $64.4-128.4$ \\
Total VFA (mmol/1) & $61.40 \pm 26.51^{*}$ & $30.4-93.1$ & $98.02 \pm 20.46^{*}$ & $54.9-69.0$ \\
Acetate (\%) & $50.53 \pm 4.66^{* *}$ & $44.5-57.8$ & $61.20 \pm 4.87^{* *}$ & $21.8-34.7$ \\
Propionate (\%) & $37.92 \pm 3.58^{* * *}$ & $31.7-42.5$ & $26.55 \pm 4.48^{* * *}$ & $8.5-14.8$ \\
Butyrate (\%) & $9.27 \pm 1.72$ & $7.5-11.6$ & $11.15 \pm 2.43$ & $0.27-0.39$ \\
Lactic acid (mmol/1) & $0.47 \pm 0.43$ & $0.26-1.36$ & $0.33 \pm 0.05$ & $2.92-5.81$ \\
Ammonia (mmol/1) & $4.87 \pm 1.10$ & $3.75-6.33$ & $3.75 \pm 1.12$ & $136-248$ \\
Number of ciliates $\left(\times 10^{3} / \mathrm{ml}\right)$ & $209 \pm 79$ & $104-312$ & $224 \pm 52$ & \\
\hline
\end{tabular}

SD - standard deviation; Range - minimum and maximum value of the indicator; VFA - volatile fatty acids ${ }^{*} P<0.05 ;{ }^{* *} P<0.01 ;{ }^{* * *} P<0.001$

The analysis of rumen fluid identified a number of significant differences between the calves in both groups (group PEL vs. group CHS). In comparison with group CHS, significantly lower mean rumen $\mathrm{pH}(5.58 \pm 0.30$ vs. $6.24 \pm 0.51)$, concentration of total VFA $(61.40 \pm 26.51$ vs. $98.02 \pm 20.46 \mathrm{mmol} / \mathrm{l})(P<0.05)$ and percentage of acetic acid $(50.53 \pm 4.66$ vs. $61.20 \pm 4.87 \%)(P<0.01)$ was found in group PEL. On the contrary,

Table 6. Comparison of average daily gains (ADG) and live weights of calves (group PEL - calves fed pelleted starter feed between days 60 to 90; group CHS - calves fed starter feed with chopped straw between days 60 to 90).

\begin{tabular}{lcccc}
\hline & \multicolumn{2}{c}{ Group PEL $(\mathrm{n}=6)$} & \multicolumn{2}{c}{ Group CHS (n=6) } \\
\cline { 2 - 5 } & Mean \pm SD & Range & Mean \pm SD & Range \\
\hline ADG (kg/day) at days 60 to 90 & $0.76 \pm 0.19$ & $0.52-0.98$ & $0.76 \pm 0.16$ & $0.57-1.07$ \\
ADG (kg/day) at days 90 to 150 & $1.13 \pm 0.54$ & $0.32-1.67$ & $1.25 \pm 0.35$ & $0.90-1.73$ \\
ADG (kg/day) at days 0 to 150 & $0.86 \pm 0.08$ & $0.74-0.96$ & $0.91 \pm 0.12$ & $0.77-1.08$ \\
Live weight of calves (kg) on day 0 & $46.50 \pm 9.42$ & $42-62$ & $45.33 \pm 5.85$ & $39-55$ \\
Live weight of calves (kg) on day 60 & $84.55 \pm 17.29$ & $56-100$ & $84.68 \pm 11.47$ & $75-106$ \\
Live weight of calves (kg) on day 90 & $107.55 \pm 18.51$ & $78-127$ & $107.59 \pm 16.04$ & $92-138$ \\
Live weight of calves $(\mathrm{kg})$ on day 150 & $175.06 \pm 21.15$ & $153-206$ & $182.43 \pm 21.22$ & $155-210$ \\
\hline
\end{tabular}

SD - standard deviation; Range - minimum and maximum value of the indicator 
significantly higher percentage of propionic acid (37.92 \pm 3.58 vs. $26.55 \pm 4.48 \%)$ $(P<0.001)$ was found in group PEL compared to group CHS. In addition, the mean decrease in the rumen fluid $\mathrm{pH}$ below the value of 6.2 was significantly higher in group PEL. The calculated ratio of acetate:propionate in group PEL $(1.34 \pm 0.18)$ was significantly lower than in group CHS $(2.38 \pm 0.53)$. The differences between the groups in the other studied properties of rumen fluid (Table 5) were not significant $(P>0.05)$. Comparison of the average daily gain (ADG) of calves fed different starters (from the $60^{\text {th }}$ to the $90^{\text {th }}$ day of life), and in the following period (to the $150^{\text {th }}$ day of age) when all calves were fed the same TMR, did not show any significant differences (Table 6). However, it is possible to see the trend of higher ADG increase in the calves of group CHS. The average live weight of calves fed the starter feed with chopped straw was $182.43 \pm 21.22 \mathrm{~kg}$ at day 150 compared to $175.06 \pm 21.15 \mathrm{~kg}$ in the calves from group PEL. In contrast, the average weight of the calves of group PEL at the day of birth was slightly higher $(46.5 \pm 9.4 \mathrm{~kg}$ ) compared to the calves of group CHS $(45.3 \pm 5.9 \mathrm{~kg})$.

\section{Discussion}

The rumen fluid analysis showed that the intake of different physical forms of starter feeds has a major effect on the indicators of rumen fermentation in post-weaning calves. Comparing the results of rumen fluid analysis with the recommended values for cattle, we can see especially in the group fed pelleted starter feed the tendency to acidification of the rumen content, in comparison to the group fed starter feed with chopped straw. The mean $\mathrm{pH}$ of group PEL was $5.58 \pm 0.30$, and the maximum value of the individual calf was 6.04. In all analyzed rumen fluids in group PEL, lower $\mathrm{pH}$ than the recommended range was detected [6.2 to 6.8 according to Hofírek et al. (2009) or 6.2 to 7.2 according to Kraft and Dürr (2001) and Radostits et al. (2007)]. Similarly, in the rumen fluid of group PEL low production of total VFA was observed. These values were substantially lower than the recommended 80 to $120 \mathrm{mmol} / \mathrm{l}$ (Hofírek et al. 2009). This result demonstrated low rumen fermentation activity, which may be related to poor rumen development associated with lack of structured fibre. This statement might be supported by a low proportion of acetic acid (mean concentration of $50.53 \%$ is below the recommended range $55-75 \%$ according to Hofírek et al. 2009), which is produced particularly in fibre fermentation. On the other hand, in the rumen fluid of group PEL high values of propionic acid were detected (the recommended range is 15-25\% according to Hofírek et al. 2009 or $20-25 \%$ according to Kraft and Dürr 2001). Because propionate is formed mainly in the digestion of easily degradable carbohydrates, it is evident that the starter feed composition supports its formation in an important way. However, its overproduction is one of the mechanisms of subacute ruminal acidosis (SARA) creation, which may contribute to damage of the digestive tract and disruption of the optimal ruminal ecosystem, impair nutrients utilization, etc. (Martin et al. 2006; Lettat et al. 2010; Kim et al. 2016; Sato 2016). Calculation of the acetate:propionate ratio is also used when evaluating rumen fermentation (Mirzaei et al. 2016; Kim et al. 2016). In our experiment, this ratio was significantly different between the groups PEL and CHS (1.34 \pm 0.18 vs. $2.38 \pm 0.53$, respectively). The reduction of rumen $\mathrm{pH}$ impairs the growth of cellulolytic bacteria and may result in a declining acetate:propionate ratio (Grant et al. 1990; Martin et al. 2006). According to the results of the rumen fluid analysis in our experiment, we cannot see the cause of the decrease of rumen $\mathrm{pH}$ in acute ruminal acidosis, since it is characterized by increased production of lactic acid (Nagaraja and Titgemeyer 2007; A schenbach et al. 2011 ) and an increase of total acidity. Our detected values of these indicators in both groups were within the recommended range $(0-3.3 \mathrm{mmol} / 1$ for lactic acid and 10 to 30 arbitrary units for total acidity) according to Hofírek et al. (2009). The results of the rumen fluid 
analysis of calves fed pelleted starter feed can be identified as a SARA. We can relate the results of the propionic acid overproduction, decreased acetic acid production, and rumen $\mathrm{pH}$ decrease to an insufficient intake of structured fibre. Although these calves had access to hay, its intake was not sufficient and the development of ruminal digestion was not ideal. In contrast, most of the analyzed indicators of rumen fermentation of the calves fed the starter feed with chopped straw were within the recommended range. Probably due to the intake of chopped straw and thereby structured fibre, rumen fermentation was nearly optimal. This is evident from the overall significantly higher production of total VFA, most physiological proportions of the individual volatile fatty acids (higher proportion of acetate and lower proportion of propionate), and the mean rumen $\mathrm{pH}$ of 6.24 .

Our results of the rumen fluid analysis can be compared e.g. with the results of Mirzaei et al. (2016). These authors fed calves mashed or textured starter and corn silage and reported the ranges of 4.92 to 5.55 for mean rumen $\mathrm{pH}, 123.6$ to $159.8 \mathrm{mmol} / \mathrm{l}$ for total VFA, 44.77 to $51.9 \%$ for acetate, and 36.88 to $44.03 \%$ for propionate. The highest $\mathrm{pH}$ and percentage of acetic acid with the lowest percentage of propionic acid at the same time was found in the experiment with calves fed mashed starter feed with $15 \%$ of corn silage. Similarly, Terré et al. (2013) reported an increase in rumen $\mathrm{pH}$ at 10 days after the weaning of calves fed a low or high NDF concentrate with forage provision in comparison with calves without forage provision (5.9 vs. 5.0, and 5.7 vs. 5.1, respectively). The relation between the physical form of the starter feed with straw provision and growth performance of Holstein calves was also described by Terré et al. (2015). Calves receiving straw showed a higher rumen $\mathrm{pH}$ compared to those not receiving straw.

Based on our results we can conclude that the addition of chopped straw to the starter feed for calves after weaning led to better development of the rumen fermentation as evaluated by rumen $\mathrm{pH}$, total VFA production, the proportion and ratio of acetic and propionic acids.

These significant effects of the starter feed with chopped straw on rumen fermentation indicators were not accompanied by similarly significant differences when evaluating ADG or live weight of calves (Table 6). During the experiment, when the calves were fed different starter feeds (day 60 to 90), the average daily gain of calves was fully balanced $(0.76 \mathrm{~kg}$ /day). However, in the subsequent period, when the calves of both groups were fed the same TMR, we could observe a certain tendency to achieve higher ADG and live weight in the calves of group CHS. At the end of the observation (150 days of age), the live weight of these calves was $7.4 \mathrm{~kg}$ higher than that of the calves of group PEL. Conversely, the average birth weight of calves of group PEL was $1.2 \mathrm{~kg}$ higher. However, these differences were not significant. Given the relatively low number of calves in our study, it would be desirable to continue with a similar study on a larger number of animals. This positive trend could be associated with better rumen development in connection with the previously described results of rumen fermentation (evaluated by rumen $\mathrm{pH}$, by total volatile fatty acids production, and by the proportion and ratio of acetic and propionic acids) during feeding the starter feed with chopped straw. The feeding of starter feed with chopped straw reduced the occurrence of subacute ruminal acidosis in calves.

\section{Acknowledgements}

The research was financially supported by the project IP IGA FA MENDELU no. 33/2016.

\section{References}

Aschenbach JR, Penner GB, Stumpff F, Gabel G 2011: Ruminant Nutrition Symposium: Role of fermentation acid absorption in the regulation of ruminal pH. J Anim Sci 89: 1092-1107

Bach A, Ferrer A, Ahedo J 2010: Effects of feeding method and physical form of starter on feed intake and performance of dairy replacement calves. Livest Sci 128: 82-86 
Beharka AA, Nagaraja TG, Morrill JL, Kennedy GA, Klemm RD 1998: Effects of form of the diet on anatomical, microbial, and fermentative development of the rumen of neonatal calves. J Dairy Sci 81: 1946-1955

Castells L1, Bach A, Araujo G, Montoro C, Terré M 2012a: Effect of different forage sources on performance and feeding behavior of Holstein calves. J Dairy Sci 95: 286-293

Castells L1, Bach A, Terré M 2012b: Effects of feeding different forage source on rumen fermentation and gastrointestinal tract development in young calves. J Dairy Sci 95(Suppl 1): 184

Dockalova H, Stastnik O, Krivova S, Sedlakova L, Pavlata L 2016: Effect of different physical forms of starter on feed intake and performance of calves. In: MENDELNET 2016-23 ${ }^{\text {rd }}$ International PhD Students Conference, Brno, 201-204

Franklin ST, Amaral-Phillips DM, Jackson JA, Campbell AA 2003: Health and performance of Holstein calves that suckled or were hand-fed colostrum and were fed one of three physical forms of starter. J Dairy Sci 86: 2145-2153

Grant RJ, Colenbrander VF, Mertens DR 1990: Milk fat depression in dairy cows: Role of silage particle size. J Dairy Sci 73: 1834-1842

Grenwood RH, Morril JL, Titgemeyer EC, Kennedy GA 1997: A new method of measuring diet abrasion and its effect on the development of the forestomach. J Dairy Sci 80: 2534-2541

Hofírek B, Dvořák R, Němeček L, Doležel R, Pospíšil Z et al. 2009: Diseases of Cattle. Noviko a.s., Brno, 1149 p. (in Czech)

Khan MA, Bach A, Weary DM, von Keyserlingk MAG 2016: Invited review: Transitioning from milk to solid feed in dairy heifers. J Dairy Sci 99: 885-902

Khan MA, Lee HJ, Lee WS, Kim HS, Kim SB, Ki KS, Park SJ, Ha JK, Choi YJ 2007: Starch source evaluation in calf starter: I. feed consumption, body weight gain, structural growth, and blood metabolites in Holstein calves. J Dairy Sci 90: 5259-5268

Khan MA, Weary DM, von Keyserlingk MAG 2011: Invited review: Effects of milk ration on solid feed intake, weaning and performance in dairy heifers. J Dairy Sci 94: 1071-1081

Kim YH, Nagata R, Ohtani N, Ichijo T, Ikuta K, Sato S 2016: Effects of dietary forage and calf starter diet on ruminal $\mathrm{pH}$ and bacteria in Holstein calves during weaning transition. Front Microbiol 7: 1575

Kraft W, Dürr U 2001: Clinical laboratory diagnostics in veterinary medicine. Hajko and Hajková, Bratislava, 365 p. (in Slovak)

Lettat A, Noziere P, Silberberg M, Morgavi DP, Berger C, Martin C 2010: Experimental feed induction of ruminal lactic, propionic, or butyric acidosis in sheep. J Anim Sci 88: 3041-3046

Martin C, Brossard L, Doreau M 2006: Mechanisms of appearance of ruminal acidosis and consequences on physiopathology and performances. Prod Anim 19: 93-107

Mirzaei M, Khorvash M, Ghorbani GR, Kazemi-Bonchenari M, Riasi A, Soltani A, Moshiri B, Ghaffari MH 2016: Interactions between the physical form of starter (mashed versus textured) and corn silage provision on performance, rumen fermentation, and structural growth of Holstein calves. J Anim Sci 94: 1-9

Nagaraja TG, Titgemeyer EC 2007: Ruminal acidosis in beef cattle: The current microbiological and nutritional outlook. J Dairy Sci 90: E17-E38

Pezhveh N, Ghorbani GR, Rezamand P, Khorvash M 2014: Effects of different physical forms of wheat grain in corn-based starter on performance of young Holstein dairy calves. J Dairy Sci 97: 6382-6390

Philippeau C, Martin C, Michalet-Doreau B 1999: Influence of grain source on ruminal characteristics and rate, site, and extent of digestion in beef steers. J Anim Sci 77: 1587-1596

Radostits OM, Gay CC, Hinchcliff KW, Constable PD 2007: Veterinary Medicine - A textbook of the diseases of cattle, horses, sheep, pigs, and goats. Elsevier Limited, Philadelphia, 2156 p.

Sato S 2016: Pathophysiological evaluation of subacute ruminal acidosis (SARA) by continuous ruminal $\mathrm{pH}$ monitoring. Anim Sci J 87: 168-177

Suarez-Mena FX, Heinrichs AJ, Jones CM, Hill TM, Quigley JD 2015: Digestive development in neonatal dairy calves with ether whole or ground oats in the calf starter. J Dairy Sci 98: 3417-3431

Terré M, Castells LI, Khan MA, Bach A 2015: Interaction between the physical form of the starter feed and straw provision on growth performance of Holstein calves. J Dairy Sci 98: 1101-1109

Terré M, Pedrals E, Dalmau A, Bach A 2013: What do preweaned and weaned calves need in the diet: A high fiber content or a forage source? J Dairy Sci 96: 5217-5225

Thomas DB, Hinks CE 1982: The effect of changing the physical form of roughage on the performance of the early-weaned calf. Anim Prod 35: 375-384 